\title{
Increased Amounts of a Novel Penicillin-binding Protein in a Strain of Methicillin-resistant Staphylococcus aureus Exposed to Nafcillin
}

\author{
Henry F. Chambers, Barry J. Hartman, and Alexander Tomasz \\ Department of Medicine, San Francisco General Hospital Medical Center and the University of California, San Francisco, California \\ 94110; and Laboratory of Microbiology, The Rockefeller University, New York, New York 10021
}

\begin{abstract}
In addition to the four typical penicillin-binding proteins (PBPs), a strain of heterogeneously methicillin-resistant Staphylococcus aureus produced an extra 78-kD PBP (PBP 2a) that had a low affinity for nafcillin and penicillin. Addition of nafcillin to cultures of this strain caused a rapid increase in the amount of this PBP in cell membranes. This increase occurred at subinhibitory concentrations of drug within minutes of exposure, and was blocked by inhibitors of protein and RNA synthesis. This suggests that the synthesis of PBP $2 a$ can be stimulated by exposure to beta-lactam antibiotics. This process may, in part, explain the heterogeneity in methicillin-resistant $S$. aureus.
\end{abstract}

\section{Introduction}

Penicillin-binding proteins (PBPs) ${ }^{1}$ are cell membrane-bound enzymes that catalyze the terminal steps in bacterial cell wall synthesis (1). Bacterial species may synthesize several PBPs, each serving a different function (1-3). Because to some extent one PBP can substitute for the function of another PBP, probably not all are essential for cell growth $(4,5)$.

PBPs are the targets of beta-lactam antibiotics. These antibiotics inhibit cell growth by binding covalently to the active sites of essential PBPs $(1,4)$. Although deactivation by beta-lactamase is the most common mechanism of resistance to these drugs (6), mutational alteration resulting in low affinity of target PBPs for beta-lactam antibiotics has been proposed as another mechanism of resistance to these drugs in some bacterial species (7-9), including strains of methicillin-resistant Staphylococcus aureus (MRSA) (10-13). For some bacterial strains this mechanism may be sufficient to explain the resistance observed, but for strains of MRSA it cannot account for their unique property of heterogeneous resistance $(14,15)$. That is, within a culture the vast majority of cells are susceptible and are killed at low concentrations of beta-lactam antibiotic,

Address correspondence to Dr. Chambers, 5H22 Department of Medicine, San Francisco General Hospital, 1001 Potreto Ave., San Francisco, CA 94110.

Received for publication 18 October 1984 and in revised form 7 March 1985.

1. Abbreviations used in this paper: cfu, colony-forming units; $\left[{ }^{3} \mathrm{H}\right] \mathrm{pen}$, $\left[{ }^{3} \mathrm{H}\right]$ benzylpenicillin; MIC, minimum inhibitory concentration; MRSA, methicillin-resistant Staphylococcus aureus; PBP, penicillin-binding protein; PBP 2a, 78-kD PBP; TSA, tryptic soy agar; TSB, tryptic soy broth.

J. Clin. Invest.

(c) The American Society for Clinical Investigation, Inc.

0021-9738/85/07/0325/07 \$1.00

Volume 76, July 1985, 325-331 so that only one cell in $10^{5}$, for example, can survive exposure to $50 \mu \mathrm{g} / \mathrm{ml}$ of methicillin.

When resistance is homogeneous in a strain of MRSA, most cells can survive high concentrations of methicillin. Such strains, in addition to the four PBPs typical of methicillinsusceptible strains (16), contain an additional 78-kD PBP, PBP $2 a$, that seems to be the biochemical correlate of resistance (13). Interestingly, the same PBP $2 a$ was also present in heterogeneously resistant strains of MRSA in quantities sufficient to be detectible by fluorography (B. Hartman and A. Tomasz, Phenotypic expression of methicillin resistance in heterogeneous strains of Staphylococcus aureus, Abstract no. 5, 24th Interscience Conference on Antimicrobial Agents and Chemotherapy, Washington, DC, Oct. 8-10, 1984). If acquisition of PBP 2a were the only mechanism required for methicillin-resistance, why is it that this PBP, which must be present in most cells of heterogeneously resistant strains, only protects a tiny subpopulation from being killed even at low concentrations of methicillin or other beta-lactam antibiotic?

In an effort to answer this question, we studied the effect of growth in medium containing nafcillin on the PBPs in a strain of MRSA, 67-0, that is heterogeneous in expression of resistance (17). Nafcillin was used for these experiments instead of methicillin because of the superior stability of the former antibiotic (18).

\section{Methods}

Strain 67-0. Strain 67-0 was originally isolated from a patient at San Francisco General Hospital Medical Center and produced beta-lactamase. The strain was cured of its plasmid encoding for beta-lactamase by treatment with ethidium bromide (19). After this treatment, a culture from several clones, confirmed to be free of beta-lactamase by the nitrocephin test (Glaxo Research, Ltd., Greenford, England) (20), was frozen in stock vials at $-70^{\circ} \mathrm{C}$. Quantitative subculture of strain 67-0 into tryptic soy agar (TSA) and TSA containing $50 \mu \mathrm{g} / \mathrm{ml}$ of nafcillin revealed that only one out of $10^{5}$ cells could express high level resistance.

Nafcillin selection of strain 67-NN. This strain was derived from colonies of strain 67-0 that had survived two passages on TSA that contained $50 \mu \mathrm{g} / \mathrm{ml}$ of nafcillin. This resulted in selection of organisms from the subpopulation of 67-0 that could grow in the presence of high concentrations of nafcillin. Quantitative subculture of strain 67NN on TSA and TSA containing $50 \mu \mathrm{g} / \mathrm{ml}$ of nafcillin revealed that virtually all cells could express high level resistance, which was stable for several subcultures (17). Strain 67-NN was also free of betalactamase.

Susceptibility tests. The minimum inhibitory concentration (MIC) was determined by macrotube dilution method (21) in tryptic soy broth (TSB) (Difco Laboratories, Inc., Detroit, MI) at a concentration of $2 \times 10^{5}$ colony-forming units $(\mathrm{cfu}) / \mathrm{ml}$ and at $37^{\circ} \mathrm{C}$.

The heterogeneity of strain $67-0$ and its derivative, $67-\mathrm{NN}$, was assessed by quantitative subculture from an overnight culture incubated at $37^{\circ} \mathrm{C}$. A volume of $0.1 \mathrm{ml}$ from this broth culture or its serial tenfold dilution was inoculated onto TSA containing one of several 
concentrations of nafcillin or no drug at all. After incubation for $72 \mathrm{~h}$ at $37^{\circ} \mathrm{C}$, colonies that grew were counted and the result was expressed as $\log _{10} \mathrm{cfu} / \mathrm{ml}$.

Preparation of cultures for PBP assay. For strain 67-0, colonies picked from drug-free TSA were inoculated into $2 \mathrm{ml}$ of TSB, which was incubated at $37^{\circ} \mathrm{C}$. The next day $0.5 \mathrm{ml}$ of this culture was inoculated into $100 \mathrm{ml}$ of fresh, prewarmed TSB, which was incubated at $37^{\circ} \mathrm{C}$ in a Gyrotary shaking water bath (New Brunswick Scientific Co., Inc., New Brunswick, NJ). The culture was harvested in the midexponential phase of growth, measured by nephelometry (Coleman Instruments, Oak Brook, IL), usually at a nephelos of 600 corresponding to $\sim 5 \times 10^{8} \mathrm{cfu} / \mathrm{ml}$. To prepare samples for PBP assays, we collected cells by centrifugation at $10,000 \mathrm{~g}$ for $10 \mathrm{~min}$ at $4^{\circ} \mathrm{C}$ and then resuspended them in $1 / 100$ th the original volume of TSB or $10 \mathrm{mM}$ sodium phosphate buffer, $\mathrm{pH}$ 7.0. Samples in buffer were assayed for protein to determine the protein content in paired samples in TSB.

For strain 67-NN, colonies were picked from TSA containing 50 $\mu \mathrm{g} / \mathrm{ml}$ of nafcillin and were inoculated into $2 \mathrm{ml}$ of TSB containing $10 \mu \mathrm{g} / \mathrm{ml}$ of nafcillin. After overnight incubation at $37^{\circ} \mathrm{C}$, cells were washed twice in fresh TSB to remove the nafcillin. The cells were resuspended in the original volume of TSB and $0.5 \mathrm{ml}$ was inoculated into $100 \mathrm{ml}$ prewarmed TSB, which was incubated and processed in the same manner as cultures of 67-0.

Effect of pre-exposure to nafcillin on appearance of PBPs. Nafcillin was added to an exponentially growing culture of either 67-0 or 67$\mathrm{NN}$, usually at a cell concentration of $\sim 2 \times 10^{8} \mathrm{cfu} / \mathrm{ml}$. Both the concentration of nafcillin and the duration of drug exposure varied. Samples for PBP assay were prepared as described.

Assay of PBPs in whole cells. Samples, each of $25 \mu \mathrm{l}$ of concentrated whole cells, were assayed for PBPs in either of two ways. (a) In the direct assay, $10 \mu \mathrm{g} / \mathrm{ml}$ (final concentration) of $\left[{ }^{3} \mathrm{H}\right]$ benzylpenicillin (ethyl-piperidium salt, $25 \mathrm{Ci} / \mathrm{mmol}$, [Merck, Sharp \& Dohme, West Point, PA]) was added and the sample was incubated at $37^{\circ} \mathrm{C}$ for 10 min. (b) In the competition assay, nafcillin, usually $10 \mu \mathrm{g} / \mathrm{ml}$, was added and the sample was incubated at $37^{\circ} \mathrm{C}$, usually for $10 \mathrm{~min}$; then the $\left[{ }^{3} \mathrm{H}\right]$ benzylpenicillin $\left(\left[{ }^{3} \mathrm{H}\right]\right.$ pen) was added. Subsequent steps were identical for both assays.

The reaction was stopped by adding $5 \mu \mathrm{l}$ of $50 \mathrm{mg} / \mathrm{ml}$ of nonradioactive penicillin. The sample was placed in a boiling water bath for $3 \mathrm{~min}$. Cells were lysed by incubation with $20 \mu \mathrm{l}$ of $500 \mu \mathrm{g} / \mathrm{ml}$ lysostaphin (Sigma Chemical Co., St. Louis, MO) and $100 \mu \mathrm{g} / \mathrm{ml}$ of Streptomyces globisporus muramidase (Miles Laboratories, Inc., Elkhart, IN) in $10 \mathrm{mM}$ sodium phosphate buffer, $\mathrm{pH} 7.6$, for $45 \mathrm{~min}$. PBPs were solubilized by addition of $40 \mu \mathrm{l}$ of double strength sample buffer (7). The sample was then heated in a boiling water bath for $3 \mathrm{~min}$. Paired samples, both in TSB and in buffer, but without the addition of drug or sample buffer, were assayed for protein content by the Lowry method (22). On the basis of this determination the protein content per sample was adjusted to $\sim \mathbf{4 0 0} \mu \mathrm{g}$ of cellular protein.

PBPs were separated by electrophoresis in an SDS polyacrylamide slab gel $(13,23)$. The acrylamide-bis-acrylamide ratio was $5 \% / 0.065 \%$ in the stacking gel and $10 \% / 0.13 \%$ in the separating gel. The potential difference was $75 \mathrm{mV}$ through the stacking gel and $115 \mathrm{mV}$ through the separating gel. Protein content was checked by Coomassie Blue stain. PBPs were detected by scintillation fluorography on Kodak XOmat film $(13,24,25)$. Binding of $\left[{ }^{3} \mathrm{H}\right]$ pen to PBPs, represented by the density of the band on the fluorogram, was measured by Quickscan Junior densitometer (Helena Laboratories, Beaumont, TX). The densitometer generated a curve, the area (expressed in arbitrary units) under which is proportional to the band's density.

Assay of PBPs in membrane preparations. Whole cells from 400 to $1,000 \mathrm{ml}$ of TSB were harvested in the exponential phase of growth. These were resuspended in $10 \mathrm{ml}$ of $10 \mathrm{mM}$ sodium phosphate buffer, pH 7.6. Lysostaphin at a final concentration of $50 \mu \mathrm{g} / \mathrm{ml}$; RNase (Millipore Corp., Bedford, MA), $2.5 \mu \mathrm{g} / \mathrm{ml}$; DNase (Millipore Corp.), $2.5 \mu \mathrm{g} / \mathrm{ml}$; and $\mathrm{MgCl}_{2}, 10 \mathrm{mM}$ were added. After a 60 -min incubation at $37^{\circ} \mathrm{C}$, debris and intact cells were removed by centrifugation at $7,000 \mathrm{~g}$ for $10 \mathrm{~min}$ at $4^{\circ} \mathrm{C}$. The supernatant was recovered and the
Table I. Minimum Inhibitory Concentrations $(\mu \mathrm{g} / \mathrm{ml})$ for the Parent Strain, 67-O, and its Derivative, 67-NN

\begin{tabular}{llrlrr}
\hline & \multicolumn{2}{l}{ Strain 67-O } & & \multicolumn{2}{c}{ Strain 67-NN } \\
\cline { 2 - 3 } \cline { 5 - 6 } Antibiotic & $24 \mathrm{~h}$ & $48 \mathrm{~h}$ & & $24 \mathrm{~h}$ & \multicolumn{2}{c}{$48 \mathrm{~h}$} \\
\hline Penicillin & 1 & 16 & 32 & 64 \\
Nafcillin & 4 & 256 & 256 & 256 \\
Methicillin & 8 & 512 & $>512$ & $>512$ \\
\hline
\end{tabular}

membrane pellet was collected after centrifugation at $80,000 \mathrm{~g}$ for 20 $\min$ at $4^{\circ} \mathrm{C}$. The pellet was washed once in buffer and resuspended in fresh buffer to a final protein concentration of $4 \mathrm{mg} / \mathrm{ml}$.

$200-\mu \mathrm{g}$ samples of protein in $50 \mu \mathrm{l}$ were dispensed into borosilicate tubes. Both direct and competition assays were performed, as described above. PBPs were solubilized in $25 \mu$ l of double strength buffer and the sample was placed in a boiling water bath for $3 \mathrm{~min}$.

\section{Results}

Susceptibility tests. Susceptibility tests confirmed that treatment with ethidium bromide had not affected the resistance of this strain to methicillin and other beta-lactam antibiotics. As is typical for heterogeneous strains of MRSA, MICs for 67-0 were higher when interpreted at $48 \mathrm{~h}$ than at $24 \mathrm{~h}$ (Table I) (26). MICs of strain 67-NN interpreted at $24 \mathrm{~h}$ were approximately the same as the values for 67-0 at $48 \mathrm{~h}$.

Quantitative subculture of strain 67-0 onto TSA containing nafcillin showed its heterogeneous pattern of resistance (Fig. 1). Most cells were killed upon exposure to $1.0 \mu \mathrm{g} / \mathrm{ml}$ of nafcillin (survival of one in 1,000) and only one in $10^{6}$ survived $100 \mu \mathrm{g} / \mathrm{ml}$ of nafcillin. In contrast, strain $67-\mathrm{NN}$ was homogeneous in its resistance: all cells survived until the concentration of $100 \mu \mathrm{g} / \mathrm{ml}$ of nafcillin, at which point survival dropped sharply.

These properties are characteristic for heterogeneous resistance and have been attributed to the presence within the total population of two subpopulations (14, 15): a methicillinsusceptible population representing the vast majority of cells and a very small population (in the case of $67-0$, one in $10^{6}$

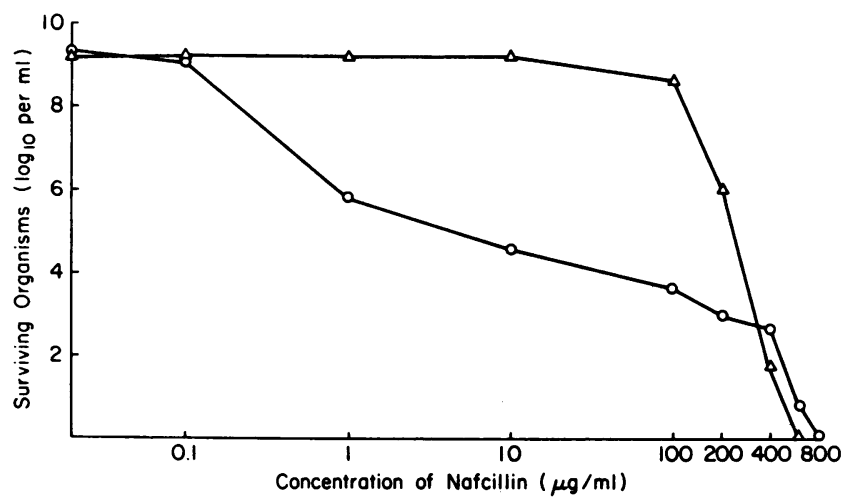

Figure 1. Effect of nafcillin on survival in strains 67-0 (0) and 67-NN $(\Delta)$. An overnight culture incubated at $37^{\circ} \mathrm{C}$ was quantitatively subcultured onto TSA containing increasing concentrations of nafcillin. After incubation at $37^{\circ} \mathrm{C}$ for $72 \mathrm{~h}$, the number of organisms surviving was determined by colony count. 
cells) of highly resistant cells. By treatment of such a culture with a beta-lactam antibiotic, susceptible organisms are killed and the highly resistant subpopulation is selected out. Strain 67-NN is derived from this very minor subpopulation in 67-0 and represents a homogeneous population of highly methicillinresistant cells.

PBPs of strains 67-0 and 67-NN. Other investigators have reported that homogeneously resistant strains of MRSA, in which all the cells are highly resistant, contain an extra PBP (PBP 2a) with a low affinity for beta-lactam antibiotics (1013). Surprisingly, in a recent study, PBP $2 a$ was also detected in cells from heterogeneously resistant strains (B. Hartman and A. Tomasz, see abstract reference in Introduction), in which most cells were susceptible to methicillin. This observation was confirmed for strain $67-0$, which is also heterogeneously resistant to methicillin.

Fluorograms of PBPs from cells of either strain 67-0 or 67-NN, grown to exponential phase in TSB and directly labeled with $\left[{ }^{3} \mathrm{H}\right]$ pen, were identical (Fig. 2, lanes $a$ and $b$ ), and both were characteristic of the pattern of four normal PBPs reported for methicillin-susceptible $S$. aureus (16). In this pair of strains, no extra band indicative of PBP 2a was detected by this direct assay technique.

The PBP assay was then repeated for strain $67-\mathrm{NN}$, but this time $10 \mu \mathrm{g} / \mathrm{ml}$ of nafcillin was added to the exponentially growing culture for $90 \mathrm{~min}$. In the fluorograms of the assay of this sample, a dark band indistinguishable from PBP 2a (13) appeared between the positions of PBP 2 and PBP 3 (Fig. 2, lane $c$ ).

The molecular weight of PBP 2a is close to that of PBP 2 and possibly it was "hidden" by the latter under the assay conditions illustrated in lanes $a$ and $b$ of Fig. 2. To evaluate this possibility, the PBPs of strain 67-0 and 67-NN were reassayed, both directly and in a nafcillin competition assay, in which samples were preincubated for 10 min with $10 \mu \mathrm{g} /$ $\mathrm{ml}$ of nafcillin, before the $\left[{ }^{3} \mathrm{H}\right]$ pen was added (see Methods). PBPs 1, 2, and 3 are saturated at this concentration of nafcillin



Figure 2. Fluorogram of direct PBP assay in whole cells. PBPs are labeled 1 through 4. Lane $a$ is from a sample of strain 67-0 grown in TSB at $37^{\circ} \mathrm{C}$; lane $b$ is from strain $67-\mathrm{NN}$ grown in TSB. Lane $c$ is from $67-\mathrm{NN}$ in TSB to which $10 \mu \mathrm{g} / \mathrm{ml}$ of nafcillin was added for 90 min during the exponential growth phase. Cells were labeled for 10 min with $10 \mu \mathrm{g} / \mathrm{ml}$ of $\left[{ }^{3} \mathrm{H}\right]$ pen at $37^{\circ} \mathrm{C}$.
$(10-13,16)$ and cannot bind $\left[{ }^{3} \mathrm{H}\right]$ pen that is added after the nafcillin, and therefore these PBPs will not be visualized in the fluorogram. A low affinity PBP should not bind nafcillin at this concentration, should remain free to bind $\left[{ }^{3} \mathrm{H}\right]$ pen and, therefore, should be detectable by fluorography. The results of this experiment are shown in Fig. 3.

After competition assay, a faint band corresponding to that of PBP 2a was visible in the fluorogram from samples of both 67-0 (Fig. 3, lane $b$ ) and 67-NN (Fig. 3, lane $d$ ). Although PBP 2a is clearly detectable by this method, its intensity was much less than that seen in lane $c$ of Fig. 2.

In the next experiment, the culture of $67-\mathrm{NN}$ was prepared by the addition of $10 \mu \mathrm{g} / \mathrm{ml}$ of nafcillin to the growing cells and PBPs were assayed both directly and by competition assay (i.e., $10 \mathrm{~min}$ with nafcillin, followed by $\left[{ }^{3} \mathrm{H}\right]$ pen). An intense, dark band was again seen between the position of the bands corresponding to PBPs 2 and 3 (Fig. 3, lanes $e$ and $f$ ).

PBPs 1, 2, 3, and 4 seemed to disappear (Fig. 3, lanes $b$, $d$, $e$, and $f$ ) when nafcillin was added either during the competition assay or to the growing culture. These PBPs, although present, had been saturated by nafcillin, rendering them unavailable for binding radiolabeled $\left[{ }^{3} \mathrm{H}\right]$ pen and, therefore, undetectable by fluorography.

The fact that both the relatively susceptible strain $67-0$ and the resistant strain 67-NN contained similarly small amounts of PBP 2a when grown in the absence of nafcillin suggested that 67-NN was not merely an overproducer of PBP 2a. It seemed that only in the presence of nafcillin were large amounts of PBP 2a detectable in strain 67-NN. Several experiments were done to test the mechanism of this effect.

Exposure of strain $67-\mathrm{NN}$ to a subinhibitory concentration of nafcillin showed that growth for $90 \mathrm{~min}$ in TSB containing $0.25 \mu \mathrm{g} / \mathrm{ml}$ of drug (generation time of $37 \mathrm{~min}$ for $67-\mathrm{NN}$ )

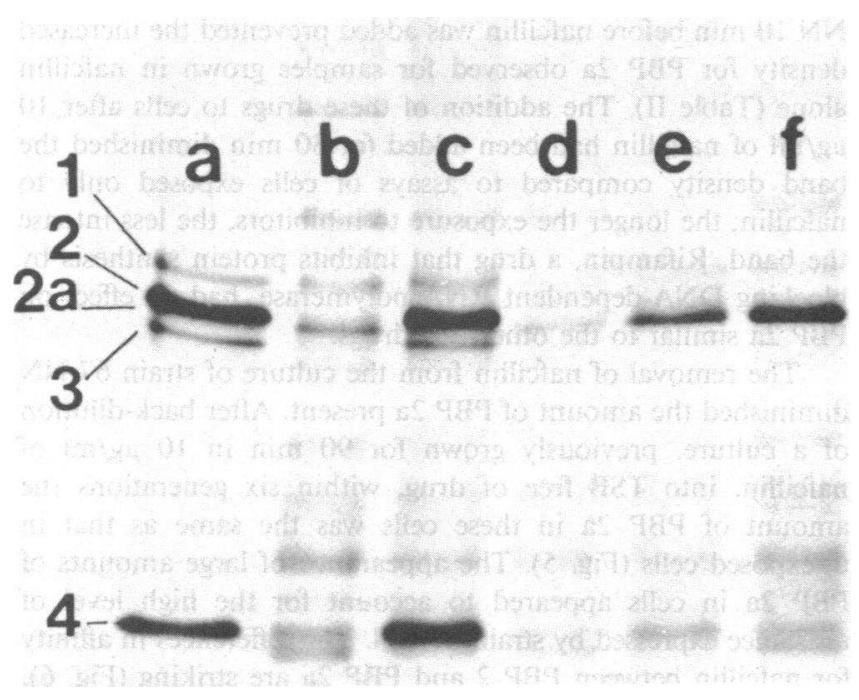

Figure 3. Fluorogram of direct and competition assays for PBPs in whole cells. PBPs are labeled 1 through 4 . Lanes $a$ and $b$ are assays of strain $67-0$ grown in TSB: (a) direct assay with $10 \mu \mathrm{g} / \mathrm{ml}$ of $\left[{ }^{3} \mathrm{H}\right]$ pen for $10 \mathrm{~min} ;(b)$ competition assay with $10 \mu \mathrm{g} / \mathrm{ml}$ of nafcillin added to the sample 10 min before $\left[{ }^{3} \mathrm{H}\right]$ pen. Lanes $c$ (direct assay) and $d$ (competition assay) are samples of strain 67-NN grown in TSB. Lanes $e$ (direct) and $f$ (competition) are samples from culture of strain $67-\mathrm{NN}$ to which $10 \mu \mathrm{g} / \mathrm{ml}$ of nafcillin was added for $90 \mathrm{~min}$ during the exponential phase of growth. 


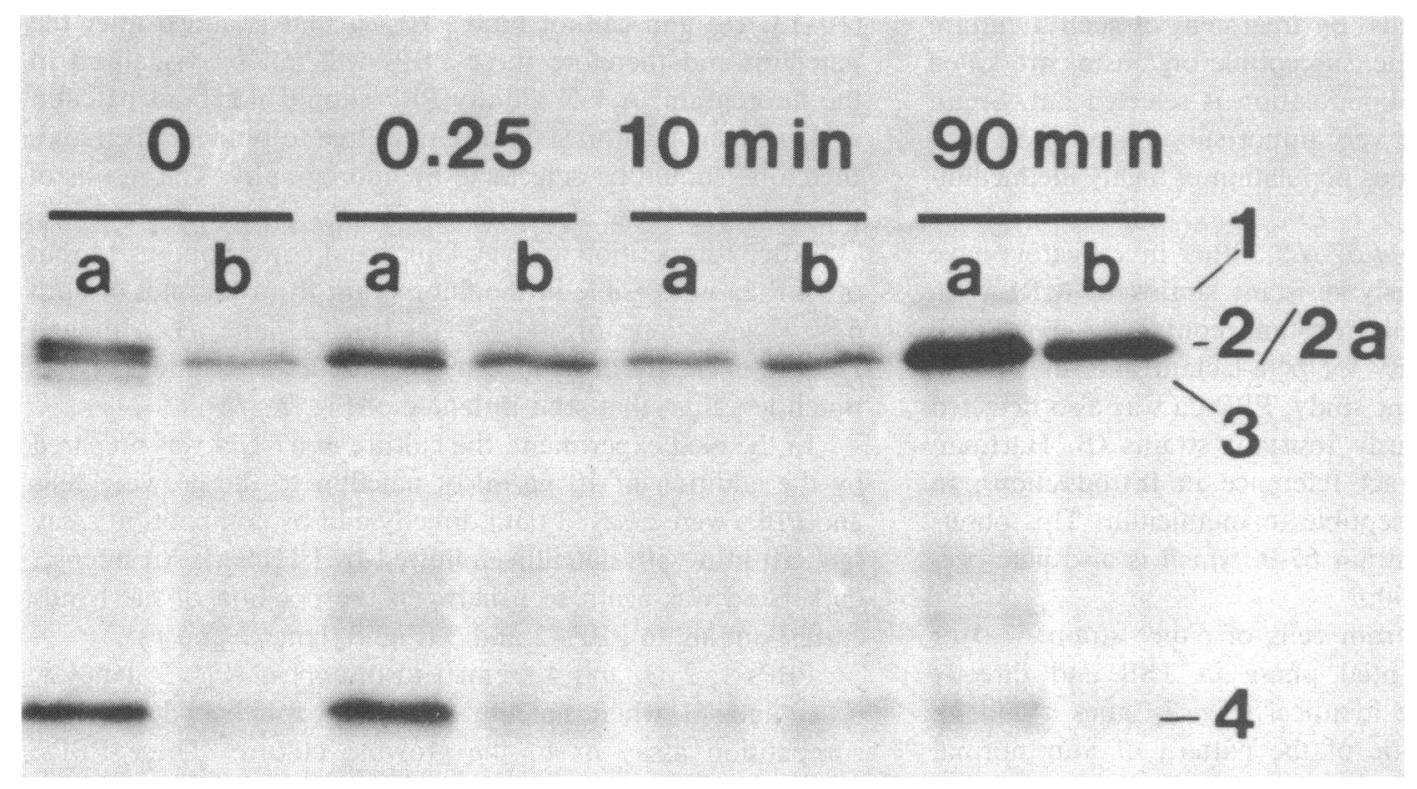

Figure 4. Fluorogram of direct (first lane in each set) and competition (second lane in each set) PBP assays of whole cells of strain 67NN grown in TSB containing no nafcillin (0), $0.25 \mu \mathrm{g} / \mathrm{ml}$ of nafcillin for $90 \mathrm{~min}, 10 \mu \mathrm{g} / \mathrm{ml}$ of nafcillin for $10 \mathrm{~min}$, and $10 \mu \mathrm{g} / \mathrm{ml} \mathrm{of}$

typically resulted in a twofold increase in the amount of PBP 2a compared to untreated samples (generation time of $36 \mathrm{~min}$ ) (Fig. 4). When cells were grown for $10 \mathrm{~min}$ in TSB containing $10 \mu \mathrm{g} / \mathrm{ml}$ of nafcillin (generation time of $49 \mathrm{~min}$ ), a similar increase was observed.

Drugs inhibiting protein synthesis at the ribosome blocked the increase in density for PBP 2a. Addition of $50 \mu \mathrm{g} / \mathrm{ml}$ of chloramphenicol or $5 \mu \mathrm{g} / \mathrm{ml}$ of tetracycline to a culture of 67 NN 10 min before nafcillin was added prevented the increased density for PBP 2a observed for samples grown in nafcillin alone (Table II). The addition of these drugs to cells after 10 $\mu \mathrm{g} / \mathrm{ml}$ of nafcillin had been added for $30 \mathrm{~min}$ diminished the band density compared to assays of cells exposed only to nafcillin; the longer the exposure to inhibitors, the less intense the band. Rifampin, a drug that inhibits protein synthesis by blocking DNA-dependent RNA polymerase, had an effect on PBP 2a similar to the other two drugs.

The removal of nafcillin from the culture of strain 67-NN diminished the amount of PBP 2a present. After back-dilution of a culture, previously grown for $90 \mathrm{~min}$ in $10 \mu \mathrm{g} / \mathrm{ml}$ of nafcillin, into TSB free of drug, within six generations the amount of PBP $2 a$ in these cells was the same as that in unexposed cells (Fig. 5). The appearance of large amounts of PBP 2a in cells appeared to account for the high level of resistance expressed by strain $67-\mathrm{NN}$. The differences in affinity for nafcillin between PBP 2 and PBP 2a are striking (Fig. 6). For strain $67-\mathrm{NN}$ grown in $10 \mu \mathrm{g} / \mathrm{ml}$ of nafcillin for $60 \mathrm{~min}$, incubation of samples for $10 \mathrm{~min}$ at concentrations up to 100 $\mu \mathrm{g} / \mathrm{ml}$ of nafcillin in competition assays caused a $50 \%$ or less decrease in the density of PBP 2a. Complete elimination of the band occurred at $600 \mu \mathrm{g} / \mathrm{ml}$ of nafcillin, the same concentration that in TSA permitted no colony formation. When nonradioactive penicillin instead of nafcillin was added to similar samples in a competition assay, the results were the same at approximately $1 / 10$ the concentration of nafcillin (data nafcillin for $90 \mathrm{~min}$. Direct assays were performed with $10 \mu \mathrm{g} / \mathrm{ml}$ of $\left[{ }^{3} \mathrm{H}\right]$ pen. Competition assays were performed with $10 \mu \mathrm{g} / \mathrm{ml}$ of nafcillin for $3 \mathrm{~min}$, instead of the usual $10 \mathrm{~min}$.

not shown). In contrast, for cells grown in drug-free TSB, the density of the band at this position was due almost entirely to PBP 2 and was eliminated by $1 \mu \mathrm{g} / \mathrm{ml}$ of nafcillin, a concentration close to the MIC of the susceptible cells.

Rapid appearance of large amounts of PBP $2 a$ in cells

Table II. Percent Density of PBP $2 a$ in Fluorograms for Competition PBP Assays for Strain 67-NN After Treatment by Inhibitors of Protein Synthesis*

\begin{tabular}{|c|c|c|c|c|}
\hline \multirow[b]{2}{*}{ Treatmentł } & \multicolumn{4}{|c|}{ Inhibitor } \\
\hline & None & $\begin{array}{l}\text { Chloram- } \\
\text { phenicol }\end{array}$ & $\begin{array}{l}\text { Tetra- } \\
\text { cycline }\end{array}$ & Rifampin \\
\hline & & $50 \mu g / m l$ & $5 \mu \mathrm{g} / \mathrm{ml}$ & $5 \mu \mathrm{g} / \mathrm{ml}$ \\
\hline Untreated & 38 & - & - & - \\
\hline Nafcillin alone & 100 & - & - & - \\
\hline Inhibitor for $10 \mathrm{~min}$, & & & & \\
\hline then nafcillin & - & 16 & 11 & 9 \\
\hline $\begin{array}{l}\text { Nafcillin, then } \\
\text { inhibitor for } 10\end{array}$ & & & & \\
\hline $\begin{array}{l}\min \\
\text { Nafcillin, then } \\
\text { inhibitor for } 30\end{array}$ & - & 69 & 71 & 85 \\
\hline $\min$ & - & 43 & 27 & 65 \\
\hline
\end{tabular}

* Values shown are the percent density of PBP $2 \mathrm{a}$ in cells after treatment compared with that of PBP $2 a$ in assays of cells grown for 30 min in TSB containing $10 \mu \mathrm{g} / \mathrm{ml}$ of nafcillin.

¥ At a cell density of $\sim 2 \times 10^{8} \mathrm{cfu} / \mathrm{ml}$ an exponentially growing culture of 67 $\mathrm{NN}$ was split into $100-\mathrm{ml}$ volumes. The untreated culture was harvested 30 min later. The nafcillin-treated culture was harvested $30 \mathrm{~min}$ after the addition of $10 \mu \mathrm{g} / \mathrm{ml}$ of nafcillin to the culture. For cultures treated with both nafcillin and inhibitor, either the inhibitor was added $10 \mathrm{~min}$ before the nafcillin, $10 \mu \mathrm{g} /$ $\mathrm{ml}$, for $\mathbf{3 0} \mathrm{min}$ and then the cells were harvested; or the inhibitor was added after the $\mathbf{3 0}$ min nafcillin treatment, and then the cells were harvested both 10 $\mathrm{min}$ and $30 \mathrm{~min}$ later. 


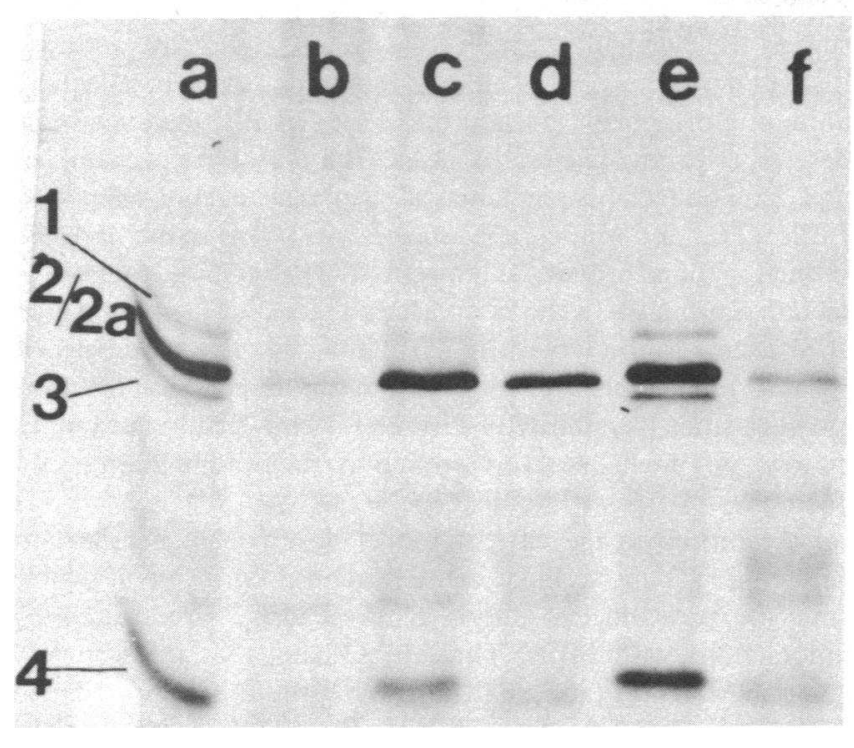

Figure 5. Fluorogram of direct and competition PBP assays of strain 67-NN before, during, and after nafcillin exposure. Lanes $a$ (direct) and $b$ (competition, $10 \mu \mathrm{g} / \mathrm{ml}$ of nafcillin) are samples from a culture grown in TSB at $37^{\circ} \mathrm{C}$. Lanes $c$ (direct) and $d$ (competition) are from a culture grown for $90 \mathrm{~min}$ in TSB to which $10 \mu \mathrm{g} / \mathrm{ml}$ of nafcillin was added. Lanes $e$ (direct) and $f$ (competition) are samples from a subculture of the culture from which samples for $c$ and $d$ were obtained, that was back-diluted into nafcillin-free TSB and harvested after six generations of growth.

highly resistant to nafcillin compared with cells relatively susceptible to nafcillin might be the explanation for the heterogeneous resistance of this strain to this and other betalactam antibiotics. To evaluate this possibility, we studied the early effect of nafcillin upon the growth both of strain 67-0 and strain 67-NN (Fig. 7). During the first $30 \mathrm{~min}$ of exposure to nafcillin, the effect on each culture was similar: growth

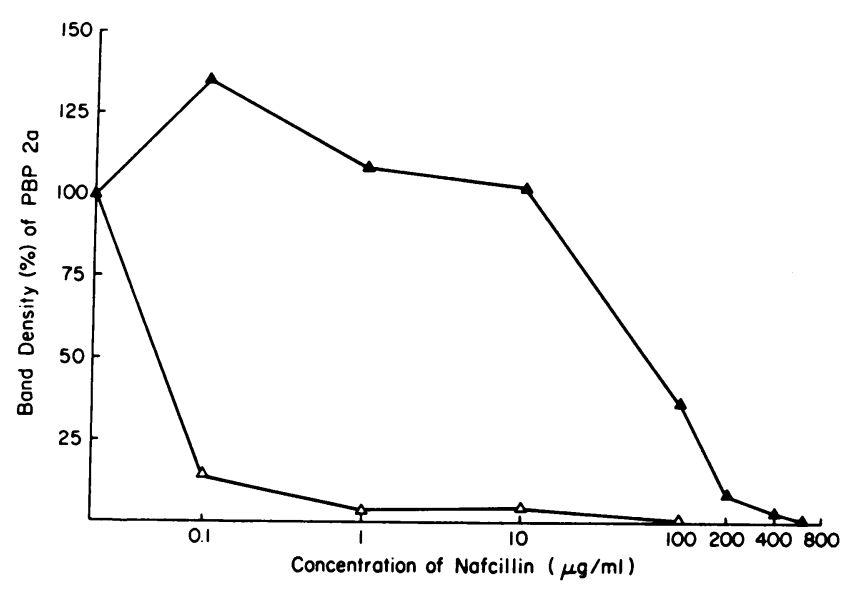

Figure 6. Density of PBP 2a as percent of control in fluorograms of samples of whole cells of strain 67-NN grown either in TSB free of nafcillin $(\Delta)$ or for $60 \mathrm{~min}$ in TSB containing $10 \mu \mathrm{g} / \mathrm{ml}$ of nafcillin (৯). Samples were incubated for $10 \mathrm{~min}$ at each of several concentrations of nafcillin, then with $10 \mu \mathrm{g} / \mathrm{ml}$ of $\left[{ }^{3} \mathrm{H}\right]$ pen for $10 \mathrm{~min}$. Density was measured and the result expressed as the percent of density of band corresponding to PBP 2 and PBP 2a present in control samples incubated only with $\left[{ }^{3} \mathrm{H}\right]$ pen.



Figure 7. Effect of $10 \mu \mathrm{g} / \mathrm{ml}$ of nafcillin upon growth of strains $67-0$ $(0)$ and $67-\mathrm{NN}(\Delta)$. Nafcillin was added at $0 \mathrm{~min}$ to $100 \mathrm{ml}$ cultures in TSB incubated at $37^{\circ} \mathrm{C}$ in a shaking water bath. Growth was determined both by nephelometry and by numbers of surviving organisms per milliliter measured by quantitative subculture onto TSA.

continued at similar rates when measured by nephelometry; viable counts did not change. During the second 30 -min interval, viable counts for strain $67-\mathrm{NN}$ began to increase, but were still unchanged for strain 67-0. In subsequent intervals, cells of 67-0 began to die, while those of $67-\mathrm{NN}$ continued to grow.

The amounts of PBP 2a present in cells of both strains exposed to nafcillin for 30 and $60 \mathrm{~min}$ were determined to see if these corresponded to the pattern of growth. Fluorograms of PBP assays of membranes of strain 67-0 showed that, like the derived strain $67-\mathrm{NN}$, the density of the band corresponding to PBP 2a was increased by growth in nafcillin (Fig. 8, top). Thus, the amounts of PBP 2a produced in strain 67-0 preexposed to nafcillin were significantly less both at $30 \mathrm{~min}$ and at 60 min than for stain $67-\mathrm{NN}$ (Table III).

The bottom panel of Fig. 8 is a photograph of a Coomassie Blue-stained gel from one of the four sets of membrane preparations. The band indicated by the arrows is superimposable onto the band for PBP 2a in fluorograms. In this set and in all others, the dark staining of the protein band at the position of PBP 2a shows that PBP 2a is a major membrane protein of cells exposed to nafcillin (lanes $c$ and $d$ ). No such band is detectable in membranes of cells grown in drug-free broth (lanes $a$ and $b$ ). No changes are apparent in any other protein bands.

\section{Discussion}

These experiments provide further evidence that PBP 2a mediates methicillin resistance in strains of $S$. aureus. PBP 2a has been detected only in resistant strains $(10,11,13,16)$. It is absent or unavailable for binding when cells are grown in broth of $\mathrm{pH} 5.2$ (13), a condition that suppresses expression of resistance. Relatively small amounts of PBP 2a are present in the membrane of the heterogeneous strain 67-0. Furthermore, PBP 2a saturates at approximately the same concentrations of 

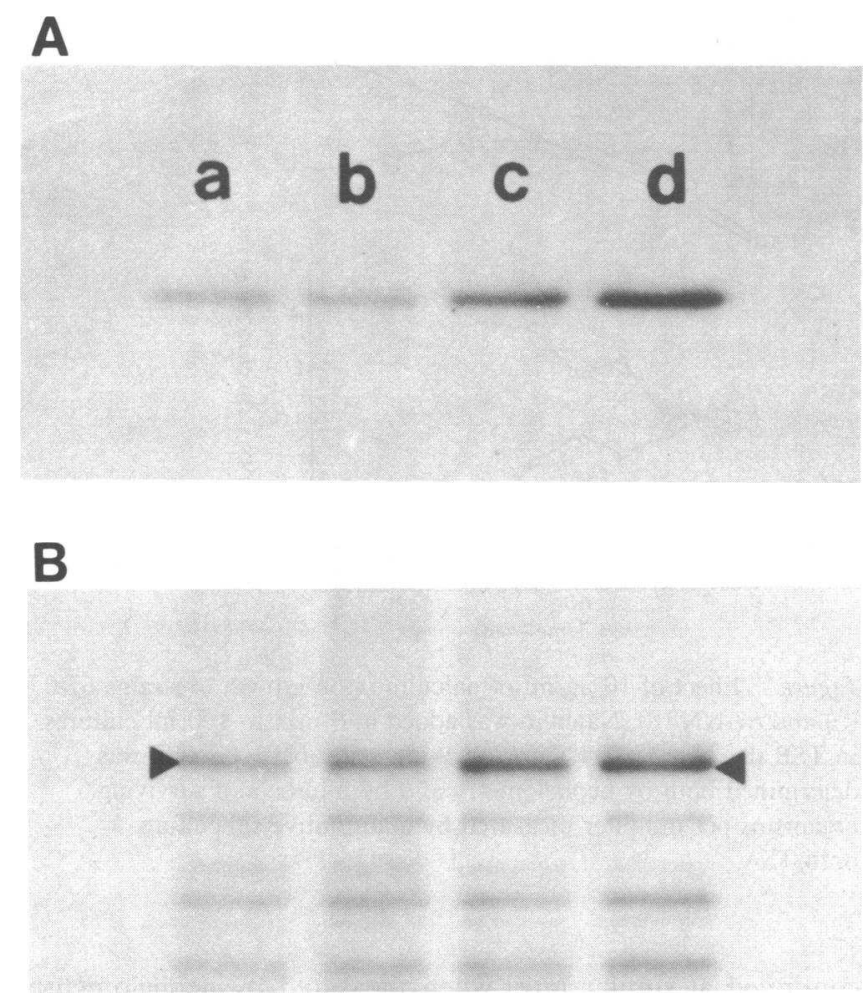

Figure 8. Typical fluorogram $(A)$ and photograph from the stained gel $(B)$ of competition PBP assays of membranes prepared from strain 67-0 grown in TSB $(a)$ and TSB containing $10 \mu \mathrm{g} / \mathrm{ml}$ of nafcillin for $30 \mathrm{~min}(c)$; and from 67-NN grown in TSB $(b)$ and TSB containing $10 \mu \mathrm{g} / \mathrm{ml}$ of nafcillin for $30 \mathrm{~min}(d) .5 \mathrm{ml}$ from an overnight culture was inoculated into $1,200 \mathrm{ml}$ of TSB at $37^{\circ} \mathrm{C}$. At nephelos 400 the culture was divided into 400 - and $800-\mathrm{ml}$ volumes; $10 \mu \mathrm{g} / \mathrm{ml}$ of nafcillin was added to the latter. The untreated culture was harvested $60 \mathrm{~min}$ later. Half of the treated culture was harvested after $30 \mathrm{~min}$ and half after $60 \mathrm{~min}$. Membranes were prepared as described in Methods and the protein content, which was checked in duplicate by the Lowry method, was adjusted to $200 \mu \mathrm{g}$ in a volume of $50 \mu \mathrm{l}$. Nafcillin, $10 \mu \mathrm{g} / \mathrm{ml}$, for $10 \mathrm{~min}$ was used in these competition assays. Arrows indicate the position of PBP 2a in the Coomassie Blue-stained gel.

beta-lactam antibiotics that inhibit cells when resistance is maximally expressed $(10,13)$.

These experiments also showed that nafcillin caused growing cells to increase substantially the amount of PBP $2 a$ in the membrane. Cells grown in sub-MIC concentrations of nafcillin produced more PBP $2 \mathrm{a}$ than cells grown in drug-free broth, and this effect was independent of the generation times. Removal of nafcillin was followed by a return of PBP 2a to baseline levels. The effect required both ongoing DNA transcription and new protein synthesis, because inhibition of either, before or after nafcillin was added, blocked the appearance of PBP 2a. The Coomassie Blue staining of gels from membrane preparations of cells exposed to nafcillin showed one clear difference from unexposed cells: the exposed cells produced large amounts of a darkly staining protein at the same position where PBP 2a was found. No such band occurred in unexposed cells.

As a possible explanation of the above observations, we suggest that nafcillin, either directly or indirectly, induces increased synthesis of PBP $2 \mathrm{a}$. Induction by a beta-lactam antibiotic of either a normal or an altered PBP has not been described for any bacterial species. The only related examples are induction of beta-lactamases, proteins possibly related to PBPs (27), and, in certain species of Gram-negative rods, induction of a protein or proteins (28) that may trap betalactam antibiotics in the periplasmic space and thereby reduce their access to the target site (29). Our observations described in this report seem to represent a fundamentally different process, since the affinity of PBP $2 a$ for beta-lactam antibiotics is low, not high; and this protein is membrane-bound, not secreted.

According to the current model of action of beta-lactam antibiotics (1), intracellular concentrations of drug are negligible and the physiological effects of these drugs are caused by interactions with PBPs. Thus, it is likely that the observed effect of nafcillin (and penicillin) on PBP 2a is also mediated via some interaction with PBPs. Such an interaction with the beta-lactam antibiotic would invoke a novel role for PBPs in transmission across the cell membrane of a regulatory signal leading eventually to increased amounts of PBP $2 a$.

Our observations may represent a novel aspect of the mechanism for heterogeneous resistance in MRSA. Data in Table III suggest that the relatively methicillin-susceptible cells of strain $67-0$ are killed by beta-lactam antibiotics because nafcillin-stimulated production of PBP 2a may be inadequate to provide sufficient numbers of copies of PBP 2a to allow continued cell wall synthesis in the presence of antibiotic.

On the other hand, in the resistant fraction of cells (represented by strain 67-NN), production of PBP 2a occurs faster, providing sufficient copy number even at high concentrations of drug that saturate other PBPs. Inspection of the data in Table III shows that for strain 67-0, the incremental increase in PBP 2a was $59 \%$ after $30 \mathrm{~min}$ and $68 \%$ after $60 \mathrm{~min}$ in medium that contained nafcillin. In contrast, for 67-NN the incremental increases were $160 \%$ and $242 \%$, respectively. Thus, the basic difference between phenotypically susceptible (majority population) and resistant (minority population) cells might be in the regulation of the rate of transcription or translation of the structural gene for PBP 2a. Further studies are needed to test this hypothesis and to clarify the exact mechanisms by which exposure to nafcillin and related drugs results in the increased cellular concentration of PBP 2a.

Table III. Densitometry Measurements of PBP $2 a$ in Membrane Preparations by Competition Assays with $10 \mu \mathrm{g} / \mathrm{ml}$ of Nafcillin*

\begin{tabular}{llll}
\hline & \multicolumn{3}{l}{ Nafcillin exposureł } \\
\cline { 2 - 4 } Source & None & $\begin{array}{l}10 \mu \mathrm{g} / \mathrm{ml}, \\
30 \mathrm{~min}\end{array}$ & $\begin{array}{l}10 \mu \mathrm{g} / \mathrm{ml}, \\
60 \mathrm{~min}\end{array}$ \\
\hline Strain 67-O & $1,370 \pm 540(4)$ & $2,180 \pm 822(4) \S$ & $2,300 \pm 240(3)^{\prime \prime}$ \\
Strain 67-NN & $1,450 \pm 780(4)$ & $3,770 \pm 630(4) \S$ & $4,960 \pm 780(3)^{\prime \prime}$
\end{tabular}

* Values are mean \pm SD.

¥ See Fig. 8 for details of these experiments. Parentheses indicate number of membrane preparations assayed.

$\S P<0.05$ by $t$ test.

" $P<0.005$ by $t$ test. 


\section{Acknowledgment}

Special thanks to Dr. Thomas Dougherty and Dr. Merle Sande for guidance and assistance.

This work was supported in part by Public Health Service Grant AI 16794 from the National Institutes of Health.

\section{References}

1. Tipper, D. J., and A. Wright. 1979. The structure and biosynthesis of bacterial cell walls. In The Bacteria: A Treatise on Structure and Function. Vol. VII. J. R. Sokatch and L. N. Ornsteon, editors. Academic Press, Inc., New York. 291-426.

2. Spratt, B. G. 1975. Distinct penicillin-binding proteins involved in the division, elongation, and shape of Escherichia coli K 12. Proc. Natl. Acad. Sci. USA. 72:2999-3003.

3. Wyke, A. W., J. B. Ward, M. V. Hayes, and N. A. Curtis. 1981. A role for penicillin-binding protein-4 of Staphylococcus aureus. Eur. J. Biochem. 119:389-393.

4. Spratt, B. G. 1977. Properties of the penicillin-binding proteins of Escherichia coli K 12. Eur. J. Biochem. 72:341-352.

5. Iwaya, M., and J. L. Strominger. 1977. Simultaneous deletion of D-alanine carboxypeptidase IB-C and penicillin-binding component IV in a mutant of Escherichia coli K 12. Proc. Natl. Acad. Sci. USA. 74:2980-2984.

6. Neu, H. C. 1979. Penicillins. In Principles and Practice of Infectious Diseases. G. L. Mandell, R. G. Douglas, and J. E. Bennett, editors. John Wiley and Sons, New York. 218-238.

7. Buchanan, C. E., and J. L. Strominger. 1976. Altered penicillinbinding components in penicillin-resistant mutants of Bacillus subtilis. Proc. Natl. Acad. Sci. USA. 73:1816-1820.

8. Dougherty, T. J., A. E. Koller, and A. Tomasz. 1980. Penicillinbinding proteins of penicillin-sensitive and intrinsically resistant Neisseria gonorrhoea. Antimicrob. Agents Chemother. 18:730-737.

9. Zighelboim, S., and A. Tomasz. 1980. Penicillin-binding proteins of multiply antibiotic-resistant Streptococcus pneumoniae. Antimicrob. Agents Chemother. 17:434-442.

10. Brown, D. F., and P. E. Reynolds. 1980. Intrinsic resistance to beta-lactam antibiotics in Staphylococcus aureus. FEBS (Fed. Eur Biochem. Soc.) Lett. 122:275-278.

11. Hayes, M. V., N. A. Curtis, A. W. Wyke, and J. B. Ward. 1981. Decreased affinity of a penicillin-binding protein for beta-lactam antibiotics in a clinical isolate of Staphylococcus aureus resistant to methicillin. FEMS (Fed. Eur. Microbiol. Soc.) Microbiol. Lett. 10: 119-122.

12. Wyke, A. W., J. B. Ward, and M. V. Hayes. 1982. Synthesis of peptidoglycan in vivo in methicillin-resistant Staphylococcus aureus. Eur. J. Biochem. 127:553-558.

13. Hartman, B. J., and A. Tomasz. 1984. Low affinity penicillinbinding protein associated with beta-lactam resistance in Staphylococcus aureus. J. Bacteriol. 158:513-516.

14. Sabath, L. D., and S. J. Wallace. 1971. Factors influencing methicillin resistance in staphylococci. Ann. NY Acad. Sci. 182:258266.
15. Matthews, P. R., and P. R. Stewart. 1984. Resistance heterogeneity in methicillin-resistant Staphylococcus aureus. FEMS (Fed. Eur. Microbiol. Soc.) Microbiol. Lett. 22:161-166.

16. Georgopapadakou, N. H., and F. Y. Liu. 1980. Binding of beta-lactam antibiotics to penicillin-binding proteins of Staphylococcus aureus and Streptococcus faecalis: relation to antimicrobial activity. Antimicrob. Agents Chemother. 18:834-836.

17. Chambers, H. F., C. J. Hackbarth, T. A. Drake, M. G. Rusnak, and M. A. Sande. 1984. Endocarditis due to methicillin-resistant Staphylococcus aureus in rabbits: expression of resistance to betalactam antibiotics in vivo and in vitro. J. Infect. Dis. 149:894-903.

18. Thornsberry, C., J. Q. Caruthers, and C. N. Baker. 1973. Effect of temperature on the in vitro susceptibility of Staphylococcus aureus to penicillinase-resistant penicillins. Antimicrob. Agents Chemother. 4: 263-269.

19. Bouanchaud, D. H., M. R. Scavizzi, and Y. A. Chabbert. 1969. Elimination by ethidium bromide of antibiotic resistance in enterobacteria and staphylococci. J. Gen. Microbiol. 54:417-425.

20. O'Callaghan, C. H., A. Morris, S. M. Kirby, and A. H. Shingler. 1972. Novel method for detection of beta-lactamase by using a chromogenic cephalosporin substrate. Antimicrob. Agents Chemother. 1:283-288.

21. Washington, J. A., and V. L. Sutter. 1980. Dilution susceptibility test: agar and macrobroth dilution procedure. In Manual of Clinical Microbiology. 3rd Edition. E. H. Lennett, A. Balows, W. H. Hausler, and J. P. Truant, editors. American Society for Microbiology, Washington, DC. 453-458.

22. Lowry, O. H., N. J. Rosebrough, A. L. Farr, and R. J. Randall. 1951. Protein measurement with the folin phenol reagent. J. Biol. Chem. 193:265-275.

23. Laemmli, U. K. 1970. Cleavage of structural protein during assembly of the head of bacteriophage T4. Nature (Lond.). 227:680685.

24. Bonner, W. M., and R. A. Laskey. 1975. A film detection method for tritium-labeled proteins and nucleic acids in polyacrylamide gels. Eur. J. Biochem. 46:83-88.

25. Laskey, R. A., and A. D. Mills. 1975. Quantitative film detection of ${ }^{3} \mathrm{H}$ and ${ }^{14} \mathrm{C}$ in polyacrylamide gels by fluorography. Eur. J. Biochem. 56:335-341.

26. Barry, A. L., and R. E. Bodal. 1977. Reliability of the microdilution technique for detection of methicillin-resistant strains of Staphylococcus aureus. Am. J. Clin. Pathol. 67:489-495.

27. Waxman, D. J., and J. L. Strominger. 1982. Beta-lactam antibiotics: biochemical modes of action. In The Chemistry and Biology of Beta-Lactam Antibiotics. Vol. III. R. B. Morin and M. Gorman, editors. Academic Press, Inc., New York. 210-285.

28. Gootz, T. D., C. C. Sanders, and R. V. Goering. 1982. Resistance to cefamandole: derepression of beta-lactamase by cefoxitin and mutation in Enterobacter cloacae. J. Infect. Dis. 146:34-42.

29. Then, R. J., and P. Angehrn. 1982. Trapping of nonhydrolyzable cephalosporins by cephalosporinase in Enterobacter cloacae and Pseudomonas aeruginosa as a possible resistance mechanism. Antimicrob. Agents Chemother. 21:711-717. 